\title{
МАРКЕРИ ОБМІНУ СПОЛУЧНОЇ ТКАНИНИ У ХВОРИХ $З$ ДІАБЕТИЧНИМИ АРТРОПАТІЯМИ
}

\author{
Орленко В. Л., \\ к. мед. н., ст. наук. сп., завідуюча науково-консультативним відділом, ДУ «Інститут \\ ендокринології та обміну речовин ім. В.П. Комісаренка НАМН України, м. Київ, Україна, \\ ORCID ID: https://orcid.org/0000-0002-8400-576X
}

Іваськіва К. Ю., к. мед. н., ст. наук. сп., ДУ «Інститут ендокринології та обміну речовин ім. В.П. Комісаренка НАМН України, м. Київ, Украӥна, ORCID ID: https://orcid.org/0000-0003-1680-4663

Добровинська О. В., к. мед. н., наук. сп., ДУ «Інститут ендокринологї та обміну речовин ім. В.П. Комісаренка НАМН України, м. Київ, Украӥна, ORCID ID: https://orcid.org/0000-0001-7689-9946

DOI: https://doi.org/10.31435/rsglobal_ws/30062020/7112

\section{ARTICLE INFO}

Received: 22 April 2020

Accepted: 12 June 2020

Published: 30 June 2020

\section{KEYWORDS}

diabetes mellitus, diabetic arthropathy, joints, chondrocytes,

Cartilage Oligomeric Matrix Protein - COMP, collagenase.

\begin{abstract}
The aim of our study was to investigate markers of connective tissue metabolism (COMP level) and indicators that reflect the synthetic and catabolic phases of the metabolism of the main components of connective tissue - collagen and glycosaminoglycans in patients with diabetic arthropathy.

The study involved 87 patients with diabetes. Patients were examined using a visual analogue scale of the Leken index and WOMAK. Cartilage oligomeric matrix Protein (COMP) was determined using enzyme immunoassay.

Results. The presence of diabetic arthropathy was detected in $78 \%$ of patients with type 1 diabetes and in $80 \%$ of patients with type 2 diabetes. In the vast majority of patients, the joints of the upper extremities were involved in the pathological process. A direct correlation was established between the presence of arthropathy and the COMP level $(r=0.76$, $\mathrm{p}=0.001)$, the Leken index $(\mathrm{r}=0.76, \mathrm{p}=0.001)$, YOUR scale $(\mathrm{r}=0.88$, $\mathrm{p}=0.001)$ and WOMAK $(\mathrm{R}=0.88, \mathrm{p}=0.001)$. Patients with type 1 diabetes with joint damage are characterized by a compensatory increase in the synthesis of subchondral bone in response to increased collagen breakdown. For patients with type 1 diabetes with joint damage is characterized by a compensatory increase in subchondral bone synthesis in response to increased collagen breakdown.

Conclusions: The results suggest that arthropathy in patients with type 1 and type 2 diabetes is characterized by an increase in the cartilage degradation marker in direct proportion to the severity and number of affected joints.
\end{abstract}

Citation: Valeriia Orlenko, Kateryna Ivaskiva, Olena Dobrovynska. (2020) Markers of Connective Tissue Metabolism in Patients with Diabetic Arthropathy. World Science. 6(58), Vol.2. doi: 10.31435/rsglobal_ws/30062020/7112

Copyright: (C) 2020 Valeriia Orlenko, Kateryna Ivaskiva, Olena Dobrovynska. This is an open-access article distributed under the terms of the Creative Commons Attribution License (CC BY). The use, distribution or reproduction in other forums is permitted, provided the original author(s) or licensor are credited and that the original publication in this journal is cited, in accordance with accepted academic practice. No use, distribution or reproduction is permitted which does not comply with these terms.

Вступ. На сьогоднішній час цукровий діабет (ЦД) належить до глобальних медикосоціальних проблем. Це обумовлено не лише прогресуючим зростанням кількості хворих на ЦД, але й надзвичайно високим ризиком розвитку його ускладнень, які призводять до втрати працездатності, інвалідизації та передчасної смерті цієї категорії хворих. 
Одним із ускладнень цього захворювання $є$ діабетичні артропатії (ДА), які при тривалому перебігу сприяють розвитку контрактур, обмеженню рухливості суглобів, супроводжуються хронічним больовим синдромом, що врешті знижує якість життя хворих та призводить до ранньої інвалідизації. Ураження суглобів у хворих на цукровий діабет $\epsilon$ достатньо частим ускладненням. Так, за даними досліджень останніх років, більш ніж у 50\% хворих на ЦД 1 та 2 типу діагностують артропатію або діабет-асоційований остеоартрит [1], але відомі лише фрагментарні дослідження стосовно чинників та механізмів розвитку, клініки та діагностики цього ускладнення.

В загальній популяції дегенеративно-дистрофічні ураження суглобів переважно розвиваються у хворих старших за 60 років. Проте на тлі ЦД зміни в суглобах розвиваються значно раніше і можуть діагностуватись навіть у молодих людей $[2,3]$. ДА представляють собою дегенеративний процес, що залучає хрящ, синовівальну мембрану та субхондральну кістку і розвивається на тлі тривалих метаболічних порушень та дисбалансу процесів біомеханічного стресу. Але найбільш вразливим, на думку багатьох дослідників, є саме хрящ. Зміни в хрящі безпосередньо пов'язані зі змінами метаболізму в хондроцитах. Адже, єдиним енергетичним субстратом для хондроцитів є виключно анаеробно метаболізована глюкоза [4]. Гіперглікемія через активацію поліолового шляху метаболізму глюкози та неферментативного глікозування білків може викликати пошкодження м'язів та периартикулярних тканин [5]. Таким чином, метаболічні процеси, які $є$ наслідком гіперглікемії, являються основними чинниками, що викликають характерні для ЦД пошкодження суглобів - артропатії, які останніми роками називають «діабетасоційованими остеоартритами».

Впродовж останнього десятиріччя йде активний пошук ранніх маркерів змін суглобових структур, які б дозволили виявляти ознаки ураження тканин суглобів (синовіальної оболонки, хряща і субхондральної кісткової тканини) вже на початковій стадії захворювання, оцінювати ступінь ураження і прогноз; призначати адекватне лікування. Останніми роками все більше робіт, які доводять, що в патологічний процес залучені всі структури суглоба - хрящ, сіновіальна рідина, субхондральна кістка [6].

В даний час вивчаються біомаркери, які дозволять кількісно оцінити ремоделювання суглоба і прогресування захворювання. Велике значення мають, як правило, молекули або молекулярні фрагменти, які присутні в хрящі, кістках і синовіальній оболонці, Вони можуть бути специфічні для одного типу суглобової тканини або бути спільними для всіх. У зв'язку з цим, все більшу зацікавленість до застосування в практиці виявляють до використання нового маркера ураження хряща - олігомірного матриксного протеїну хряща (Cartilage Oligomeric Matrix Protein СОМР). На теперішній час доведено, що рівень СОМР в сироватці крові корелює 3 тяжкістю деградації хряща і $€$ потенційним прогностичним маркером при запальних захворюваннях суглобів [7-9]. Результати досліджень також демонструють зв'язок підвищеного рівня СОМР в сироватці 3 прогресуванням деструкції суглобового хряща, що спостерігається при моніторингу радіографічним методом [10,11]. СОМР, який також називають тромбоспондином 5 (TSP 5), відносять до не колагенових глікопротеїнів (кальцій-зв'язуючий білок), який має велику молекулярну масу (> 500 кДа), він присутній у позаклітинному матриксі хрящів суглобів, носа і трахеї.

Інтактний COPM зв'язує колаген I, II, IX типу i, було висловлено припущення, що молекули СОМР відіграють важливу роль в підтримці властивостей і цілісності колагенової сітки. СОМР переважно виявляється в тканинах хряща; в значно меншій кількості протеїн присутній у зв'язках, меніску і синовіальній мембрані. Молекули СОМР зв'язують між собою колагенові волокна, стабілізуючи колагенову мережу тканини хряща $[12,13]$.

Крім того, СОМР може виконувати функції зберігання і доставки гідрофобних молекул клітинного сигналінгу, таких як вітамін D. Значущість COMP в нормальному розвитку i функціонування хряща була підкреслена відкриттям мутацій в гені СОМР, що призводить до псевдохондроплазії і деяких форм множинної епіфізарної дисплазії. [12]. При захворюваннях, які супроводжуються пошкодженням хряща, матриксні протеїни потрапляють у синовіальну рідину і потім в кров ще до морфологічно вираженого руйнування хряща $[13,14]$. Дослідження останніх років показали, що виявлення підвищених концентрацій СОМР є більш чутливим методом діагностики хрящової деструкції, ніж рентгенологічні зміни.

Таким чином, олігомірний матриксний протеїн хряща $\epsilon$ раннім і перспективним маркером ремоделювання суглобового хряща. 
Мета роботи. Метою нашого дослідження було дослідити маркери обміну сполучної тканини у хворих $з$ діабетичними артропатіями, а саме рівень СОМР у сироватці крові хворих на ЦД 1 та 2 типу з артропатіями та визначити взаємозв'язок з функціональними індексами, які характеризують клінічні прояви ураження суглобів у хворих на цукровий діабет, а також вивчити показники, що відображають синтетичну і катаболическую фази метаболізму основних компонентів сполучної тканини - колагену і глікозаміногліканів.

Матеріали та методи. У дослідженні прийняло участь 87 пацієнтів (33 чоловіка та 53 жінки). Хворі були розподілені на дві групи в залежності від типу ЦД. Так, з ЦД 1 типу було 42 осіб (20 чоловіків та 22 жінки), з ЦД 2 типу -45 хворих (15 чоловіків та 30 жінок). Таким чином, у групі пацієнтів з ЦД 1 типу виявлено рівномірний розподіл за статтю $(\mathrm{t}=1,36 ; \mathrm{p}>0,1)$, а у групі пацієнтів з ЦД 2 типу переважають жінки $(\mathrm{t}=3,8 ; \mathrm{p}<0,001)$. Середнє значення віку пацієнтів та їх ІМТ очікувано значимо нижче, ніж у групі пацієнтів з ЦД 2 типу $(\mathrm{p}<0,001)$. У даній вибірці середній IMТ вищий у групі пацієнтів з ЦД 2 типу, ніж у групі пацієнтів з ЦД 1 типу на $24,2 \%(\mathrm{t}=10.5 ; \mathrm{p}=0.001)$. За тривалістю ЦД групи статистично не відрізнялись $(\mathrm{p}>0,07)$. Відмінностей за вивченими показниками за статтю не виявлено $(\mathrm{p}>0,2)$.

Вміст глюкози в крові визначали глюкозооксидазним методом. Ступінь компенсації вуглеводного обміну обстежених пацієнтів оцінювали за рівнем глікованого гемоглобіну

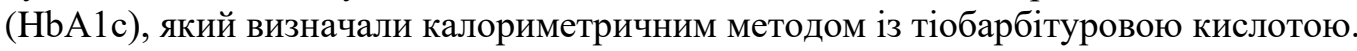

Вираженість болю оцінювалася за 10 сантиметровою візуальною аналоговою шкалою (ВАШ). Цей тест відбивав загальну вираженість суглобового болю за оцінкою хворого, де 0 означає відсутність болю, а 10-максимальну інтенсивність болю.

Альгофункціональний індекс Лекена (Lequesne) включав оцінку болю у спокої та при ходьбі. Він являє собою відкритий опитувальний лист для самостійного заповнення хворим (4 питання). Відповідь на кожне питання оцінюється в балах від 0 до 2. Тяжкість ураження суглобів визначається сумою балів: 1-4 - слабо виражений, легкий; 5-7 - середньої важкості, помірний; 810 - виражений, важкий; 11-12 - значно виражений, дуже важкий; більше 12 - вкрай важкий.

Визначався індекс WOMAC (Western Ontario and McMAster Universities Osteorthritis Index), який характеризує вираженість больового синдрому, скутість і функціональну активність. Індекс WOMAC є опитувальник для самостійного заповнення хворим, складається 3 24 питань, які характеризують вираженість болю (5 питань), скутість (2 питання), функціональну здатність (17 питань) у хворих ОА.

Наявність та ступінь вираженості діабетичної артропатії оцінювали за методикою та класифікацією A. Rosenbloom. (1982), за якою виділяли три ступеня: 1 ступінь (легкий) характеризується порушенням обсягу рухів 1 чи 2 проксимальних міжфалангових, 1-го великого суглоба або тільки двобічним обмеженням рухливості метакарпальнофалангових суглобів; 2 ступінь (помірний) - проявляється порушенням обсягу рухів 3-х і більше проксимальних міжфалангових суглобів або двобічним обмеженням рухливості метакарпальнофалангових та одного з великих суглобів; 3 ступінь (тяжкий) - характеризується явною деформацією кисті, наявністю контрактури Дюпюітрена, поєднанням контрактур кистей рук з ураженням шийного відділу хребта чи великих суглобів.

Вміст СОМР в зразках сироватки крові визначали методом твердофазного імуноферментного аналізу з використанням наборів Human COMP ELISA фірми BioVender (Чеська Республіка). Статистична обробка отриманих даних проводилася за допомогою методів варіаційної статистики стандартного пакета для статистичних підрахунків Statistica 5.0 Microsoft OffiseExel 2003. У роботі наведені статистичні показники середніх величин (що позначаються як M), а також середнє квадратичне відхилення (SD), стандартна помилка середньої величини (m). Для порівняння середніх абсолютних величин у різних досліджуваних групах застосовувався t-критерій Стьюдента. Різниця в отриманих результатах вважалась статистично достовірною при величині показника $\mathrm{p} \leq 0,05$. Для аналізу даних також були використані кореляційний, дисперсійний однофакторний, множинний регресійний аналіз, а також дискримінантна статистика.

Результати. Діабетичну артропатію виявлено у 33 (78\%) обстежених хворих на ЦД 1 типу. У переважній більшості (28 хворих) скарги були на болі у суглобах верхніх кінцівок - у 10 осіб суглобів кисті, у 15 - суглобів кисті та плечового суглобу. У 8 - поєднання суглобів кисті та колінних або кульшових суглобів. У хворих на ЦД 2 типу ураження суглобів 
діагностовано у 36 (80\%) хворих. У переважної більшості з них (20 осіб) скарги були на болі в суглобах кисті та одному великому суглобі (плечовому -10 , колінному-7, кульшовому 3). Болі були симетричними 3 обох боків. При обстеженні зовнішніх ознак запального процесу не виявлено, температура навколосуглобових тканин не відрізнялася від норми. Тривалість діабетичної артропатії була від 1 до10 років.

При порівнянні середніх показників встановлено вірогідне підвищення всіх функціональних індексів у хворих з діабетасоційованими остеоартритами (табл. 1). Так, показник ВАШ, який відображає інтенсивність болю був вірогідно вищим як у хворих на ЦД 1 ( $\mathrm{t}=-6$, $\mathrm{p}=0,001)$, так і 2 типу ( $\mathrm{t}=-6,9, \mathrm{p}=0,001)$. Це свідчить про вираженість больового синдрому у хворих з ураженнями суглобів в порівнянні з хворими на ЦД без артропатій. Больовий синдром у хворих на ЦД іноді важко віддиференціювати, адже хворі з артропатіями, як правило, мають інші ускладнення цукрового діабету, такі як полінейропатія, ангіопатія, клінічним симптом яких теж може бути больовий синдром. Тому контрольною групою для пацієнтів з артропатіями слугували хворі на ЦД без ураження суглобів, які не відрізнялись по наявності інших ускладнень ЦД. Отже, за таких умов нашого дослідження, ми можемо стверджувати, що саме артропатія призводить до вірогідно вищого больового синдрому у обстежених нами хворих.

Таблиця 1. Порівняння середніх значень показників при відсутності/наявності артропатії при різному типу ЦД

\begin{tabular}{|c|c|c|c|c|c|}
\hline \multirow[b]{2}{*}{ ЦД } & \multirow[b]{2}{*}{ Показники } & \multicolumn{2}{|c|}{ артропатія } & \multirow[b]{2}{*}{$\mathrm{t}$} & \multirow[b]{2}{*}{$\mathrm{p}$} \\
\hline & & $\begin{array}{c}\text { відсутня } \\
\text { n=9 }\end{array}$ & $\begin{array}{c}\text { наявна } \\
\mathrm{n}=33\end{array}$ & & \\
\hline \multirow{4}{*}{ ЦД 1 тип } & індекс Лекена & $8,1 \pm 1,2$ & $15,2 \pm 0,5$ & $-5,5$ & 0,001 \\
\hline & ВАШ & $2,1 \pm 0,5$ & $5,9 \pm 0,3$ & $-6,0$ & 0,001 \\
\hline & WOMAK & $30,3 \pm 3,5$ & $52,4 \pm 2,1$ & $-5,4$ & 0,001 \\
\hline & олігоматриксний білок хряща & $12,5 \pm 0,7$ & $25,2 \pm 1,6$ & $-7,1$ & 0,001 \\
\hline & & \multicolumn{2}{|c|}{ артропатія } & \multirow[b]{2}{*}{$\mathrm{t}$} & \multirow[b]{2}{*}{$\mathrm{p}$} \\
\hline & & $\begin{array}{c}\text { відсутня } \\
\text { n=9 }\end{array}$ & $\begin{array}{c}\text { наявна } \\
\mathrm{n}=36\end{array}$ & & \\
\hline \multirow{4}{*}{ ЦД 2 тип } & індекс Лекена & $7,7 \pm 0,9$ & $14,5 \pm 0,4$ & $-6,9$ & 0,001 \\
\hline & ВАШ & $2,3 \pm 0,3$ & $4,9 \pm 0,4$ & $-5,3$ & 0,001 \\
\hline & WOMAK & $25,2 \pm 2,3$ & $48,6 \pm 1,9$ & $-7,8$ & 0,001 \\
\hline & олігоматриксний білок хряща & $13,4 \pm 1,1$ & $22,4 \pm 1,1$ & $-5,7$ & 0,001 \\
\hline
\end{tabular}

Індекс Ленкена вважається найбільш надійним в оцінці тяжкості порушення функцій великих суглобів. Ми отримали вірогідні зміни у хворих 3 артропатіями при обох типах захворювання $(\mathrm{t}=-5,5, \mathrm{p}=0,001)-$ у хворих на ЦД 1 типу, $(\mathrm{t}=-6,9, \mathrm{p}=0,001)-$ у хворих на ЦД 2 типу.

Індекс WOMAK дає можливість оцінити функціональний стан суглобів, який теж вірогідно був гіршим у хворих з ураженнями суглобів при обох типах захворювання $(\mathrm{t}=-5,4$, $\mathrm{p}=0,001) ;(\mathrm{t}=-7,8, \mathrm{p}=0,001)-$ відповідно.

Маркер деструкцій хрящової тканини СОМР був вірогідно вищим у хворих 3 артропатіямии при обох типах захворювання в порівнянні з хворими на ЦД без захворювання суглобів $(\mathrm{t}=-7,1, \mathrm{p}=0,001) ;(\mathrm{t}=-5,7, \mathrm{p}=0,001)$ відповідно (табл. 2$)$.

Ми проаналізували як вищевказані показники змінюються в залежності від стадії артропатії. Середні показники олігомірного матриксного білку хряща вірогідно збільшуються 3 прогресуванням ураження та кількістю задіяних в запальний процес суглобів. Ми бачимо вірогідне підвищення даного показника 3 кожною стадією артропатії $(\mathrm{t}=-3,4, \mathrm{p}=0,005 ; \mathrm{t}=-2,4$, $\mathrm{p}=0,0023 ; \mathrm{t}=-3,2, \mathrm{p}=0,006)$ у хворих на ЦД 1 типу. У хворих на цукровий діабет 2 типу вірогідні зміни виявлені між відсутністю артропатії та іiі 1 стадією та $(\mathrm{t}=-3,4, \mathrm{p}=0,001)$ між 1 та 2 стадіями $(\mathrm{t}=-4,1, \mathrm{p}=0,001)$; достовірних змін між 2 та 3 стадіями не виявлено $(\mathrm{t}=-2,2, \mathrm{p}=0,0101)$; $(\mathrm{t}=-3,2, \mathrm{p}=0,006)$ Таким чином, олігомірний матриксний білок хряща може бути використаний в діагностиці діабетасоційованих остеоартритів, а його рівень відображати наявність та ступінь порушення ремодулятивних процесів хрящової тканини. 
Ідекс Лекена вірогідно збільшувався 3 прогресуванням артропатії у хворих на ЦД 1 типу, $(\mathrm{t}=-3,6, \mathrm{p}=0,003-; \mathrm{t}=-2,2, \mathrm{p}=0,0036 ; \mathrm{t}=-2,4, \mathrm{p}=0,003-$ відповідно $)$, тоді як у хворих на ЦД 2 типу вірогідні зміни були виявлені у хворих між відсутністю захворювання суглобів та 1 стадією артропатії $(\mathrm{t}=-4,9, \mathrm{p}=0,001)$ та між хворими 31 та 2 стадією ураження суглобів $(\mathrm{t}=-4,5, \mathrm{p}=0,001)$, тоді як достовірних змін в величині Індексу Лекена між 2 та 3 стадією артропатій встановлено не було $(\mathrm{t}=-2,2, \mathrm{p}=0,068)$.

Вираженість больового синдрому, оцінена за анкетою ВАШ, вірогідно зростала із підвищенням стадії артропатії у хворих на ЦД обох типів. Так, у хворих на ЦД 1 типу достовірні зміни були встановлені між всіма стадіями артропатії $(\mathrm{t}=-2,7, \mathrm{p}=0,016 ; \mathrm{t}=-4,3, \mathrm{p}=0,001$; $\mathrm{t}=-5,6, \mathrm{p}=0,001)$, у хворих на ЦД 2 типу між групою з відсутністю змін у суглобах та 1 стадією артропатії вірогідних змін не виявлено $(\mathrm{t}=-0,8, \mathrm{p}=0,428)$ між 1 та 2,2 та 3 стадіями встановлено вірогідні відмінності $(\mathrm{t}=-5,8, \mathrm{p}=0,001 ; \mathrm{t}=-7,1 \mathrm{p}=0,001)$ відповідно. Тобто, у хворих на ЦД 2 типу больовий синдром був значно сильніший з вираженими змінами в суглобах.

Функціональні можливості хворого та якість життя оцінювали за шкалою WOMAK. У хворих на ЦД 1 типу вірогідні зміни встановлені тільки між групами пацієнтів без артропатії та з iii 1 стадією ( $\mathrm{t}=-2,3, \mathrm{p}=0,009)$, між 1 та 2 стадіями, а також між 2 та 3 стадією вірогідних змін не виявлено $(\mathrm{t}=-2,0, \mathrm{p}=0,061 ; \mathrm{t}=-1,0, \mathrm{p}=0,351)$ відповідно, тоді як у хворих з ЦД 2 типу із збільшенням стадії артропатії вірогідно погіршувались і функціональні можливості хворого $(\mathrm{t}=-4,0, \mathrm{p}=0,001 ; \mathrm{t}=-4,9, \mathrm{p}=0,001, \mathrm{t}=-7,1 \mathrm{p}=0,001)$.

Таблиця 2. Порівняння середніх значень показників при різних стадіях артропатії та типі ЦД

\begin{tabular}{|l|c|c|c|c|c|c|c|c|}
\hline \multirow{2}{*}{ Стадії артропатії } & \multicolumn{2}{|c|}{ індекс Лекена } & \multicolumn{2}{|c|}{ ВАШ } & \multicolumn{2}{c|}{ WOMAK } & \multicolumn{2}{c|}{$\begin{array}{c}\text { олігоматриксний } \\
\text { білок хряща }\end{array}$} \\
\cline { 1 - 10 } & $\mathrm{N}$ & $\mathrm{M} \pm \mathrm{m}$ & $\mathrm{N}$ & $\mathrm{M} \pm \mathrm{m}$ & $\mathrm{N}$ & $\mathrm{M} \pm \mathrm{m}$ & $\mathrm{N}$ & $\mathrm{M} \pm \mathrm{m}$ \\
\hline ЦД 1 тип & 42 & $13,7 \pm 0,7$ & 42 & $5,1 \pm 0,4$ & 42 & $47,7 \pm 2,3$ & 42 & $22,5 \pm 1,5$ \\
\hline відсутня артропатія & 9 & $8,1 \pm 1,2$ & 9 & $2,1 \pm 0,5$ & 9 & $30,3 \pm 3,5$ & 9 & $12,5 \pm 0,7$ \\
\hline 1 стадія & 10 & $13,0 \pm 0,7$ & 10 & $3,9 \pm 0,4$ & 10 & $44,9 \pm 3,4$ & 10 & $18,1 \pm 1,5$ \\
\hline 2 стадія & 15 & $15,3 \pm 0,8$ & 15 & $6,0 \pm 0,3$ & 15 & $54,0 \pm 3,0$ & 15 & $24,5 \pm 2,1$ \\
\hline з стадія & 8 & $18,0 \pm 0,9$ & 8 & $8,1 \pm 0,2$ & 8 & $58,9 \pm 4,0$ & 8 & $35,2 \pm 2,6$ \\
\hline ЦД 2 тип & 45 & $13,1 \pm 0,6$ & 45 & $4,4 \pm 0,3$ & 45 & $43,9 \pm 2,1$ & 45 & $20,6 \pm 1,1$ \\
\hline відсутня артропатія & 9 & $7,7 \pm 0,9$ & 9 & $2,3 \pm 0,3$ & 9 & $25,2 \pm 2,3$ & 9 & $13,4 \pm 1,1$ \\
\hline 1 стадія & 12 & $12,3 \pm 0,3$ & 12 & $2,8 \pm 0,4$ & 12 & $37,9 \pm 2,2$ & 12 & $17,5 \pm 0,8$ \\
\hline 2 стадія & 20 & $15,2 \pm 0,6$ & 20 & $5,6 \pm 0,3$ & 20 & $51,7 \pm 1,8$ & 20 & $23,1 \pm 1,1$ \\
\hline 3 стадія & 4 & $17,5 \pm 0,9$ & 4 & $8,0 \pm 0,6$ & 4 & $64,8 \pm 0,2$ & 4 & $33,2 \pm 4,4$ \\
\hline
\end{tabular}

Таблиця 3. Статистичні відмінності середніх значень показників при різних стадіях артропатії та типу ЦД

\begin{tabular}{|c|c|c|c|c|c|c|c|c|c|c|c|c|}
\hline Показники & \multicolumn{6}{|c|}{ ЦД 1 тип } & \multicolumn{6}{|c|}{ ЦД 2 тип } \\
\hline & \multicolumn{2}{|c|}{$\begin{array}{c}\text { Відсутня/ } \\
1 \text { ст }\end{array}$} & \multicolumn{2}{|c|}{$\begin{array}{l}1 \mathrm{ct} / \\
2 \mathrm{ct}\end{array}$} & \multicolumn{2}{|c|}{$\begin{array}{l}2 \mathrm{ct} / \\
3 \mathrm{ct}\end{array}$} & \multicolumn{2}{|c|}{$\begin{array}{c}\text { Відсутня/ } \\
1 \text { ст }\end{array}$} & \multicolumn{2}{|c|}{$\begin{array}{l}1 \mathrm{cT} / \\
2 \mathrm{cT}\end{array}$} & \multicolumn{2}{|c|}{$\begin{array}{l}2 \mathrm{ct} / \\
3 \mathrm{ct}\end{array}$} \\
\hline И-с Лекена & $-3,6$ & 0,003 & $-2,2$ & 0,036 & $-2,4$ & 0,030 & $-4,9$ & 0,001 & $-4,5$ & 0,001 & $-2,2$ & 0,068 \\
\hline ВАШ & $-2,7$ & 0,016 & $-4,3$ & 0,001 & $-5,6$ & 0,001 & $-0,8$ & 0,428 & $-5,8$ & 0,001 & $-3,8$ & 0,015 \\
\hline WOMAK & $-3,0$ & 0,009 & $-2,0$ & 0,061 & $-1,0$ & 0,351 & $-4,0$ & 0,001 & $-4,9$ & 0,001 & $-7,1$ & 0,001 \\
\hline COMP & $-3,4$ & 0,005 & $-2,4$ & 0,023 & $-3,2$ & 0,006 & $-3,0$ & 0,010 & $-4,1$ & 0,001 & $-2,2$ & 0,101 \\
\hline
\end{tabular}

Ми провели кореляційний аналіз між наявністю артропатії та вивченими показниками (табл. 3). Було встановлено пряму кореляційну залежність між наявністю артропатії та рівнем $\operatorname{COMP}(\mathrm{r}=0,76, \mathrm{p}=0,001)$. Крім того сильної сили прямий кореляційний зв'язок був виявлений між наявністю артропатії та індексом Лекена $(\mathrm{r}=0,76, \mathrm{p}=0,001)$, шкалою ВАШ $(\mathrm{r}=0,88$, $\mathrm{p}=0,001)$ та WOMAK $(\mathrm{r}=0,88, \mathrm{p}=0,001)$.

Ми також вивчили показники, що відображають синтетичну і катаболічну фази метаболізму основних компонентів сполучної тканини - колагену і глікозаміногліканів. 
Експериментальними дослідженнями доведено, що вільна фракція гідроксипроліну, яка утворюється при розпаді колагену, не може бути повторно включена в метаболічні процеси на відміну від інших амінокислот (за винятком гідроксилізину). Тому відхилення від нормальних величин концентрації вільної фракції гідроксипроліну дозволяє судити про катаболізм колагену, тобто є біохімічним маркером резорбції кісткової і хрящової тканин, оскільки основним білком цих тканин $є$ колаген. Гідроксипролін - амінокислота, яка $є$ специфічним маркером колагенових білків. Показано, що до 40\% знову синтезованого колагену руйнується внутрішньоклітинно, ще не будучи секретованим [15]. Особливістю його обміну є те, що в біосинтез колагену включається пролін, гідроксилювання якого відбувається всередині фібробласту. Тому поява гідроксипроліну в сироватці крові $\epsilon$ результатом катаболічних процесів сполучної тканини і може відображати ступінь активності цього процесу. Ремоделювання (тобто деградація або протеоліз) колагенових волокон внутрішньоклітинного матриксу хрящової і кісткової тканини проводиться за допомогою матриксних металопротеїназ (ММП). Активність різних ММП (колагеназ) має надзвичайно широкий спектр біологічних наслідків, оскільки вони деградують більшість компонентів позаклітинної матриці: інтерстиціальний колаген і колаген базальної мембрани, протеоглікани, декорін, фібромодулін, фібронектин і т.д. У геномі людини присутні не менше 200 ММПподібних генів, включаючи власне ММП (25 генів), мембранно-зв'язані MMП, ADAM протеїнази (дизінтегрин-металопротеїназні домени), ADAMTS протеїнази (дизінтегрин-металопротеіназні домени 3 тромбоспондіновим мотивом) і ряд інших. Саме підвищена активність ММП лежить в основі патогенезу остеоартриту, що підтверджують і отримані нами дані [16,17].

Нами були проаналізовані основні біохімічні показники, що відображають метаболізм сполучної тканини (табл.4, табл.5).

Таблиця 4. Біохімічні показники, що відображають метаболізм сполучної тканини в сироватці крові пацієнтів з ЦД 1 типу

\begin{tabular}{|c|c|c|c|c|c|c|c|c|c|c|}
\hline \multirow{3}{*}{\begin{tabular}{|c|} 
ЦД 1 тип \\
Показники \\
\end{tabular}} & \multicolumn{8}{|c|}{ Артропатія } & \multirow{3}{*}{$\mathrm{t}$} & \multirow{3}{*}{$\mathrm{p}$} \\
\hline & \multicolumn{4}{|c|}{ відсутня } & \multicolumn{4}{|c|}{ наявна } & & \\
\hline & $\mathrm{N}$ & $\mathrm{M}$ & $\mathrm{m}$ & $\sigma$ & $\mathrm{N}$ & $\mathrm{M}$ & $\mathrm{m}$ & $\sigma$ & & \\
\hline Колагеназа мкмоль/л.год. & 9 & 3,94 & 0,12 & 0,48 & 33 & 4,94 & 0,21 & 1,01 & $-4,2$ & 0,001 \\
\hline $\begin{array}{c}\text { Гідроксипролін вільний } \\
\text { мкмоль/л }\end{array}$ & 9 & 7,15 & 0,17 & 0,68 & 33 & 7,80 & 0,16 & 0,76 & $-2,8$ & 0,008 \\
\hline $\begin{array}{c}\text { Гідроксипролін } \\
\text { б/зв'язаний, мкмоль/л }\end{array}$ & 9 & 12,51 & 0,23 & 0,93 & 33 & 12,83 & 0,13 & 0,63 & $-1,2$ & 0,242 \\
\hline ГАГ г/л & 9 & 0,056 & 0,003 & 0,011 & 33 & 0,061 & 0,003 & 0,013 & $-1,5$ & 0,150 \\
\hline Гіалуронідаза мкмоль/k & 9 & 226,81 & 2,12 & 8,49 & 33 & 228,83 & 1,31 & 6,43 & $-0,8$ & 0,426 \\
\hline
\end{tabular}

Таблиця 5. Біохімічні показники, що відображають метаболізм сполучної тканини в сироватці крові пацієнтів з ЦД 2 типу

\begin{tabular}{|c|c|c|c|c|c|c|c|c|c|c|}
\hline \multirow{3}{*}{$\begin{array}{c}\text { ЦД } 2 \text { тип } \\
\text { Показники }\end{array}$} & \multicolumn{8}{|c|}{ Артропатія } & \multirow{3}{*}{$\mathrm{t}$} & \multirow{3}{*}{$\mathrm{p}$} \\
\hline & \multicolumn{4}{|c|}{ відсутня } & \multicolumn{4}{|c|}{ наявна } & & \\
\hline & $\mathrm{N}$ & M & $\mathrm{m}$ & $\sigma$ & $\mathrm{N}$ & $\mathrm{X}$ & $\mathrm{m}$ & $\sigma$ & & \\
\hline Колагеназа мкмоль/л.год. & 9 & 3,88 & 0,24 & 0,84 & 36 & 4,47 & 0,16 & 0,80 & $-2,1$ & 0,046 \\
\hline $\begin{array}{c}\text { Гідроксипролін вільний } \\
\text { мкмоль/л } \\
\end{array}$ & 9 & 7,04 & 0,27 & 0,94 & 36 & 7,83 & 0,17 & 0,85 & $-2,6$ & 0,014 \\
\hline $\begin{array}{c}\text { Гідроксипролін б/зв'язаний, } \\
\text { мкмоль/л }\end{array}$ & 9 & 12,35 & 0,27 & 0,92 & 36 & 12,67 & 0,15 & 0,75 & $-1,1$ & 0,269 \\
\hline ГАГ г/л & 9 & 0,055 & 0,003 & 0,009 & 36 & 0,057 & 0,003 & 0,01 & $-0,5$ & 0,597 \\
\hline Гіалуронідаза мкмоль/k & 9 & 223,83 & 2,75 & 9,54 & 36 & 225,96 & 1,36 & 6,82 & $-0,8$ & 0,441 \\
\hline
\end{tabular}

Дисперсійний аналіз показав відмінності середніх показників колагенази в залежності від стадії артропатії ( $\mathrm{F}=6.7 ; \mathrm{p}<0.001)$. Відмінностей середнього рівня показника в залежності від типу діабету не виявлено $(\mathrm{p}=0.23)$. Як при ЦД 1 типу, так і при ЦД 2-го типу встановлено відмінності середнього рівня колагенази при наявності/відсутності артропатії. Так, при ЦД 1 типу і наявності артропатії рівень колагенази вище на $16,6 \%(t=3,1 ; p=0,004)$, ніж при ііі відсутності. Аналогічне значення показника при ЦД 2 типу $-17,1 \%(\mathrm{t}=2,6 ; \mathrm{p}=0,025)$. При ЦД 1 типу виявлено лінійне підвищення середнього рівня показника при прогресуванні артропатії $(\mathrm{R} 2=0.95)$. 
За результатами логіт-регресійного аналізу серед показників метаболізму сполучної тканини значущим для розвитку артропатії при цукровому діабеті визначено тільки рівень колагенази та олігоматриксного білку хряща (табл. 6.). Встановлено, що при підвищеному рівні колагенази у пацієнтів з ЦД 1 типу шанси на розвиток артропатії підвищуються в 4,4 рази, а при ЦД 2 типу майже в 6 разів ( $<<0,001)$. При підвищеному рівні олігоматриксного білка у пацієнтів з ЦД 1 типу шанси на розвиток артропатії підвищуються вдвічі $(\mathrm{p}<0,05)$, а при ЦД 2 типу в 1,8 разів $(\mathrm{p}<0,01)$.

Таблиця 6. Ймовірність розвитку артропатії в залежності від показників метаболізму сполучної тканини у пацієнтів з цукровим діабетом

\begin{tabular}{|l|c|c|c|c|c|c|c|c|}
\hline $\begin{array}{l}\text { Показники } \\
\begin{array}{l}\text { метаболізму } \\
\text { сполучної } \\
\text { тканини }\end{array}\end{array}$ & OR & ДІ & $\begin{array}{l}\text { Критерій } \\
\text { Вальда }\end{array}$ & $\mathrm{p}$ & OR & ДІ & $\begin{array}{c}\text { Критерій } \\
\text { Вальда }\end{array}$ & $\mathrm{p}$ \\
\hline колагеназа & 4,38 & $1,13-16,89$ & 4,9 & 0,001 & 5,89 & $1,21-28,83$ & 5,1 & 0,001 \\
\hline $\begin{array}{l}\text { гідроксипролін } \\
\text { вільний }\end{array}$ & 2,25 & $0,79-6,41$ & 2,5 & 0,117 & 2,4 & $0,97-6,13$ & 3,8 & 0,049 \\
\hline $\begin{array}{l}\text { гідроксипролін } \\
\text { зв'язаний }\end{array}$ & 1,45 & $0,54-3,93$ & 0,6 & 0,446 & 1,30 & $0,46-3,68$ & 0,3 & 0,607 \\
\hline ГАГ & 1,01 & $0,73-2,36$ & 1,2 & 0,384 & 0,99 & $0,75-1,20$ & 0,1 & 0,998 \\
\hline гіалуронідаза & 1,07 & $0,96-1,20$ & 1,7 & 0,195 & 1,0 & $0,90-1,11$ & 0,1 & 0,993 \\
\hline $\begin{array}{l}\text { Олігоматриксний } \\
\text { білок хряща }\end{array}$ & 2,03 & $1,09-3,81$ & 5,2 & 0,022 & 1,77 & $1,16-2,69$ & 7,3 & 0,007 \\
\hline
\end{tabular}

На рис. 1 представлено графічне зображення ранжованого відношення шансів у пацієнтів з ЦД 1 та 2 типу в залежності від рівня показників метаболізму тканини.

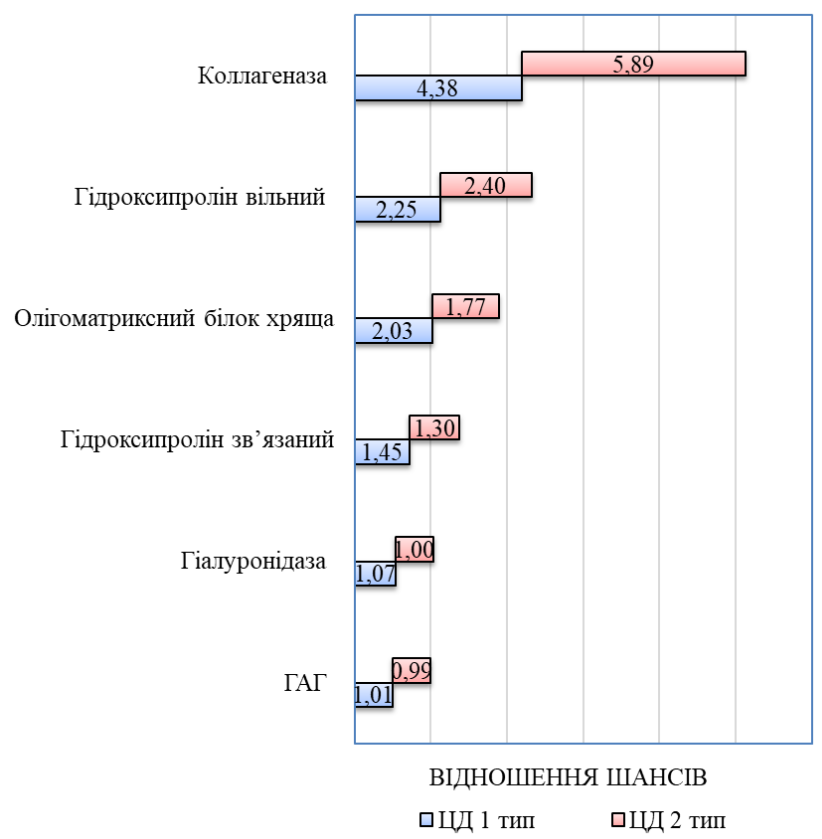

Рис. 1. Ймовірність виявлення артропатії у пацієнтів з иукровим діабетом в залежсності від рівня показників метаболізму сполучної тканини

Обговорення. Для хворих з діабетасоційованими остеоартритами характерна активація катаболічної фази метаболізму основних компонентів сполучної тканини, про що свідчить вірогідне підвищення колагенази і вільного гідроксипроліну $(\mathrm{p}<0,001)$. Виявлено прямий кореляційний зв'язок показників для жінок з ЦД 1 типу. Таким чином, для хворих на ЦД 1 типу з ураженнями суглобів характерне компенсаторне збільшення синтезу субхондральної кістки у відповідь на підвищений розпад колагену.

Діабетична артропатія є розповсюдженим ускладненням цукрового діабету, близько 80 \% хворих на ЦД обох типів, за нашими даними, мають ураження суглобів. Хоча в літературі 
до теперішнього часу дані стосовно розповсюдженості артропатій надзвичайно різняться $[18,19,20]$. Аналізуючи локалізацію артропатії як у хворих на ЦД 1 , так і у хворих на ЦД 2 типу переважають ураження суглобів верхніх кінцівок. Хоча, як відомо, особливо з віком, страждають переважно великі опорні суглоби, і саме механічне навантаження $€$ провокуючим та ініціюючим фактором, що призводить до неспецифічного запалення, запуску каскаду реакцій, які призводять до синтезу металопротеаз, порушенню ремоделювання хрящової тканини та розвитку дегенеративних змін в суглобах [21]. У хворих на ЦД як 1, так і 2 типу, незалежно від ІМТ, тривалості та компенсації захворювання, в патологічний процес переважно включаються суглоби верхніх кінцівок. Тому можна припустити, що для цієї категорії хворих характерний метаболічний фенотип остеоартриту, де основними пусковими факторами $\epsilon$ саме метаболічні порушення, які характерні для цукрового діабету - глюкозотоксичність, інсулінорезистентість, дерегуляція інсулінових рецепторів на мембрані хондроцитів.

Ми дослідили один із сучасних біохімічних маркерів деградації хряща СОМР у хворих 3 діабетасоційованими остеоартритами, оскільки чітко встановлено, що його рівень $\epsilon$ одним із чутливих методів діагностики хрящової деструкції, оскільки вже чітко показано, що підвищення його концентрації в сироватці крові передує рентгенологічним змінам суглобів [22]. На теперішній час ведуться дискусії стосовно структур суглоба, які задіяні в патологічний процес у хворих на ЦД. Багато років вважалося, що саме навколосуглобові тканини, а не хрящ $\epsilon$ основною мішенню ураження суглобів у хворих на цукровий діабет. Також висловлюється припущення, що субхондральна кістка в першу чергу зазнає змін у цієї категорії хворих [4].

Але останніми роками все більше робіт, які доводять, що в патологічний процес залучені всі структури суглоба - хрящ, сіновіальна оболонка, субхондральна кістка [19]. Але саме хрящ вражається найбільше i, в першу чергу, в сироватці крові з'являються саме маркери деградації суглобового хряща. За нашими даними, підвищення вмісту в сироватці крові СОМР виявлено у хворих з артропатіями при ЦД обох типів, отже порушення ремоделювання відбувається як за умов недостатності інсуліну, так і при інсулінорезистентності. Підвищення рівня СОМР у даної категорії хворих свідчить про порушення ремоделювання хрящової тканини 3 превалюванням процесів деградації. Встановлено, що процес руйнування підвищується зі збільшенням стадії артропатії та збільшенням кількості суглобів, задіяних в патологічний процес. Збільшення рівня маркеру деградації хряща супроводжувалось більш явною клінічною симптоматикою, а саме: погіршенням функціональних можливостей хворих, збільшенням больового синдрому, збільшенням часу вранішньої скутості. Отримані прямі позитивні кореляційні зв'язки між рівнем СОМР та кількістю балів, отриманих при аналізі стандартних опитувальників, які відображають активність та тяжкість ураження суглобів у хворих на цукровий діабет. Таким чином, підвищення рівня СОМР у хворих з артропатіями при ЦД обох типів свідчить про руйнування хряща, а його рівень відображає вираженість клінічних симптомів діабетасоційованих остеоартритів.

\section{Висновки.}

1. Діабетичну артропатію виявлено у 78 \% обстежених хворих на ЦД 1 типу та у $80 \%$ хворих на ЦД 2 типу. У переважній більшості хворих на ЦД 1 типу та ЦД 2 типу локалізація змін у суглобах переважала в верхніх кінцівках.

2. При порівнянні середніх показників встановлено вірогідне підвищення всіх функціональних індексів, які характеризують тяжкість ураження суглобів та функціональні можливості хворих у хворих з діабетасоційованими остеоартритами.

3. Середні показники СОМР вірогідно збільшуються 3 прогресуванням ураження та кількістю задіяних в запальний процес суглобів.

4. Встановлено пряму кореляційну залежність між наявністю артропатії та рівнем $\operatorname{COMP}(\mathrm{r}=0,76, \mathrm{p}=0,001)$. Крім того, сильної сили прямий кореляційний зв'язок був виявлений між наявністю артропатії та індексом Лекена $(\mathrm{r}=0,76, \mathrm{p}=0,001)$, шкалою ВАШ $(\mathrm{r}=0,88$, $\mathrm{p}=0,001)$ та WOMAK $(\mathrm{r}=0,88, \mathrm{p}=0,001)$.

5. СОМР може бути використаний як біохімічний маркер деструкції хряща та відображення клінічної активності артропатії.

6. Для хворих 3 діабет-асоційованими остеоартритами характерна активація катаболічної фази метаболізму основних компонентів сполучної тканини.

7. Для хворих на ЦД 1 типу 3 ураженнями суглобів характерне компенсаторне збільшення синтезу субхондральної кістки у відповідь на підвищений розпад колагену. 


\section{REFERENCES}

1. Haugen IK, Magnusson K, Turkiewicz A, Englund M. (2017) The Prevalence, Incidence, and Progression of Hand Osteoarthritis in Relation to Body Mass Index, Smoking, and Alcohol Consumption. J Rheumatol., 44(9), 1402-1409. doi:10.3899/jrheum.170026

2. Louati, K., Vidal, C., Berenbaum, F., Sellam, J. (2015). Association between diabetes mellitus and osteoarthritis: systematic literature review and meta-analysis. R.M.D, 1, e000077. https://doi.org/10.1136/rmdopen-2015-000077

3. Rehling T., Bjørkman A., Dam, Andersen M., Ekholm O., Molsted S. (2019) Diabetes is associated with musculoskeletal pain, ostheoarthritis, osteoporosis and rheumatoid arthritis, 2019 Article ID 6324348 https://doi.org/10.1155/2019/6324348

4. Berenbaum F. (2012). Diabetes-induced osteoarthritis: from a new paradigm to a new phenotype. Postgrad. Med. J, 88, 240-242. Doi: 10.1136/pgmj.2010.146399rep.

5. King K. B., 2015 King, K. B., \& Rosenthal, A. K. (2015). The adverse effects of diabetes on osteoarthritis: update on clinical evidence and molecular mechanisms. Osteoarthritis and Cartilage, 23(6), 841-850. Doi: 10.1016/j.joca.2015.03.031

6. Watt, F.E. (2018). Osteoarthritis biomarkers: Year in review. Osteoarthr. Cartil, 26, 312-318. https:// doi: 10.1016/j.joca.2017.10.016.

7. Starodubceva, A.I., Vasileva, L.V. (2016). Sravnitelnyi analiz urovnya oligomernogo matriksnogo proteina hrashcha v syvorotke krovi pacientov s zabolevaniyami kostno-myshechnoy sistemy [Comparative analysis of the level of oligomeric matrix cartilage protein in the serum of patients with diseases of the musculoskeletal system]. Clinical laboratory diagnostics, 6 (2), 83-86. Doi: 10.18821/0869-2084-2016-61-2-83-86 [in Russian]

8. Firner, S., Zaucke, F., Heilig, J., de Marées, M., Willwacher, S., Brüggemann, G.P., Niehoff, A. (2020). Impact of knee joint loading on fragmentation of serum cartilage oligomeric matrix protein. J. Orthop Res, 1, 1-9. Doi: 10.1002/jor.24586.

9. Hao, H.Q., Zhang, J.F., He, Q.Q., Wang, Z. (2019). Cartilage oligomeric matrix protein, C-terminal crosslinking telopeptide of type II collagen, and matrix metalloproteinase-3 as biomarkers for knee and hip osteoarthritis (OA) diagnosis: a systematic review and meta-analysis, Osteoarthritis Cartilage, 27(5), 726736. Doi: 10.1016/j.joca.2018.10.009.

10. Hoch, J.M., Mattacola, C.G., Medina McKeon, J.M., Howard, J.S., Lattermann, C. (2011). Serum cartilage oligomeric matrix protein (sCOMP) is elevated in patients with knee osteoarthritis: a systematic review and meta-analysis. Osteoarthritis and Cartilage, 19(12), 1396-1404. Doi: 10.1016/j.joca.2011.09.005

11. Hosnijeh, F.S., Siebuhr, A.S., Uitterlinden, A.G., Oei, E.H.G., Hofman, A., Karsdal, M.A., BiermaZeinstra, S.M., Bay-Jensen, A.C., van Meurs, J.B.J. (2016). Association between biomarkers of tissue inflammation and progression of osteoarthritis: Evidence from the Rotterdam study cohort. Arthritis Res. Ther, 18, 81. Doi: 10.1186/s13075-016-0976-3.

12. Posey, K.L., Hecht, J.T. (2008). The role of cartilage oligomeric matrix protein (COMP) in skeletal disease. Curr. Drug Targets, 1(9), 869-877 Doi: 10.2174/138945008785909293.

13. Acharya C., Yik J.H.N., Kishore A., Dinh V.V., Di Cesare P.E., Haudenschild D.R. (2014). Cartilage oligomeric matrix protein and its binding partners in the cartilage extracellular matrix: Interaction, regulation and role in chondrogenesis. Matrix Biol, 37, 102-111. https://doi: 10.1016/j.matbio.2014.06.001.

14. Posey, K.L., Coustry, F., Hecht, J.T. (2018). Cartilage oligomeric matrix protein: COMPopathies and beyond. Matrix Biol, 71-72, 161-173. Doi: 10.1016/j.matbio.2018.02.023.

15. Scully S. P., Lee J. W., Ghert P. M. A., Qi W. The role of the extracellular matrix in chondrocyte regulation. Clin. Orthop. Relat. Res. 2001; 391:72-89.

16. Sabah Ali, Zainab A., Sahar H., Abdul-Kareem, Heba F. Hassan, Rasha M., Shaker Rasha A. Azeez Estimation of Serum Matrix Metalloproteinases-1 Levels in Iraqi Female Patients with Osteoarthritis. Int. J. Med. Res. Health Sci. 2018; 7(5): 18-22

17. Won Gyung Gho, Yuri Choi, Kwang-Ho Park, and Jong-Ki Huh. Expression of collagenases (matrix metalloproteinase-1, 8, 13) and tissue inhibitor of metalloproteinase-1 of retrodiscal tissue in temporomandibular joint disorder patients. J. Korean Assoc. Oral Maxillofac Surg 2018. Jun; 44(3):120-126. English.

18. Jarallah, K., Shehab, D., Abdella, N. Al Mohamedy, H., Abraham, M. (2016). Knee Osteoarthritis in Type 2 Diabetes Mellitus Does Insulin Therapy Retard Osteophyte: Formation? Med. Princ. Pract, 25, 12-17 https://doi.org/10.1159/000441418

19. Sellam, J., Berenbaum, F. (2013). Is osteoarthritis a metabolic disease? Joint Bone Spine, 80, 568-573. Doi: 0.1016/j.jbspin.2013.09.007.

20. Robertson, F., Geddes, J., Ridley, D., McLeod, G., Cheng, K. (2012). Patients with type 2 diabetes mellitus have a worse functional outcome post knee arthroplasty: a matched cohort study. Knee, 19, 286-289. Doi: 10.1016/j.knee.2011.06.001.

21. Frey, N., Hugle, T., Jick, S.S., Meier, C.R., Spoendlin, J. (2016). Type II diabetes mellitus and incident osteoarthritis of the hand: apopulation-based case-control analysis. Osteoarthr Cartil, 24(9), 1535-40. Doi: 10.1016/j.joca.2016.04.005

22. Yacishin, R.Ya., Suhorembska M.Ya. (2015). Rol biomarkeriv poshkodzhennya suglobovogo hrashcha v diagnostuci ta likuvanni hvorykh na osteoartroz [ The role of biomarkers of articular cartilage damage in the diagnosis and evaluation of osteoarthritis patients]. Ukrainian Rheumatology Journal, 2(60), 37-41 [in Ukrain] 